\title{
Killer whale (Orcinus orca) ocCuRrence in Venezuelan waters, 1982-2008
}

\author{
Jaime Bolaños-JimÉnez ${ }^{2, *}$ Dagmar FertL ${ }^{3}$ and Miguel IÑíguez ${ }^{4}$
}

The assessment of the status of the small cetaceans of the Caribbean Sea was set as a priority by the Scientific Committee of the International Whaling Commission (IWC) during its $57^{\text {th }}$ Annual Meeting held in Ulsan, Korea, in 2005 (IWC, 2006). This effort was undertaken at the $58^{\text {th }}$ Annual Meeting held in St. Kitts and Nevis (IWC, 2007). Additionally, the global status of killer whales (Orcinus orca) was assessed by the IWC during its $59^{\text {th }}$ Annual Meeting held in Anchorage, Alaska, during 2007 (IWC 2008). The latter effort concluded that 'very little information on any aspect of killer whale biology in many areas hinders any assessment of their status' (IWC, 2008). This is particularly the case in tropical waters, including the Caribbean Sea, where almost no information is available (e.g. Caldwell and Caldwell, 1969; Katona et al., 1988; Dunn et al., 20075). According to Oviedo et al. (2008), the presence of killer whales in Venezuela has remained unclear. In 1978, a probable sighting of killer whales was recorded off northeastern Venezuela, but identification could not be confirmed ${ }^{6}$. Systematic cetacean surveys in several locations throughout Venezuela have not yielded sightings of this species (e.g. Evans, 1979; Notarbartolo di Sciara, 19837; Naveira-Cortizas, 1996; Molero-Lizarraga, 2005; Oviedo et al., 2005; Bolaños-Jiménez et al., 2007; Herrera-Trujillo, 2007; Silva-Hernández, 2007; Pirela et al., 20089). Recently, Acevedo-Galindo (2007) presented the potential distribution of seven cetacean species in Venezuelan waters made on the basis of contrasting topographic profiles vs. depth of sightings, but did not include the killer whale in her review because only a handful of records were available at the time. In the present note we contribute to the knowledge on the occurrence of killer whales in Venezuelan waters on the basis of opportunistic sightings.
A request for information (in particular, sightings accompanied by photographs or video footage) was sent out during early 2007 to an environmental Internet discussion list and colleagues working on marine mammals in Venezuela. Records not accompanied by photographic documentation were accepted only if they were: 1) confirmed by a marine biologist aboard the vessel, or 2) provided by an observer or source who demonstrated familiarity with diagnostic characteristics of the species, including specific mention of sexual dimorphism as indicated by shape and relative size of the dorsal fin. Whenever possible, efforts were made to interview the original observers.

Eighteen sighting records were collected, covering the time period April 1982 - January 2008 (Table 1, Figure 1). Observations form sport fishing club members, who fish year-round, accounted for $89 \%(n=16)$ of the reports. No observations of strandings or fisheries interactions were reported. Five of the 18 records were accompanied by still photographs or video (Figure 2). Bottom depth for the occurrences was 10-1500m (mean $=444 \mathrm{~m}$; SD $=405 \mathrm{~m}$; mode $=400 \mathrm{~m} ; n=18$ ). Group size ranged from 1 to 5 individuals $($ mean $=2.72 ; \mathrm{SD}=1.56 ;$ mode $=1 ; n=18$ ). Adult males were present during $72 \%$ of reported sightings; females/juveniles were present during $61 \%$ ( $n=13$ and 11, respectively). Photographs of two male killer whales (Figure 2) were sent to researchers in Brazil and Bahamas and will be available for future comparison to compiled photographs for those areas.

According to ecological and geomorphological characteristics, the Venezuelan Caribbean Sea has been divided in 12 ecoregions (Miloslavich et al., 2003; Miloslavich and Klein, 2008 ${ }^{10}$ ). Sixty-one percent of the sightings were recorded over the 'Oceanic' ecoregion and $17 \%$ over the 'Eastern Upwelling' ecoregion.

\footnotetext{
${ }^{1}$ Received on 31 July 2008. Accepted on 20 August 2009. Managed by Nélio Barros / Daniel Palaios.

2 Sociedad Ecologica Venezolana Vida Marina (Sea Vida), A.P. 162, Cagua, Estado Aragua, Venezuela 2122.

${ }^{3}$ Ziphius EcoServices, 8112 Springmoss Drive, Plano, Texas, 75025 USA, www.ziphiusecoservices.com.

${ }^{4}$ Fundación Cethus, Potosí 2087 ( B1636BUA) Olivos, Provincia de Buenos Aires, Argentina www.cethus.org and the Whale and Dolphin Conservation Society International (WDCS, www.wdcs.org).

* Corresponding author, e-mail: sea_vida@yahoo.es.

${ }^{5}$ Dunn, C.A., Claridge, D.E. and Pusser, T.L. (2007) Killer whale (Orcinus orca) occurrence and predation in the Bahamas. In Abstracts, $17^{\text {th }}$ Biennial Conference on the Biology of Marine Mammals, 29 November - 3 December 2007, Cape Town, South Africa.

${ }^{6}$ Notarbartolo di Sciara, G. (1978) Report on a sighting of unusual cetaceans in the waters adjacent to Puerto La Cruz, Venezuela. In litt.

${ }^{7}$ Notarbartolo di Sciara, G. (1983) Bryde's whales (Balaenoptera edeni Anderson, 1878) off eastern Venezuela. Hubbs-Sea World Research Institute Technical Report No. 83-153. Hubbs-Sea World Research Institute, San Diego, CA.

${ }^{8}$ Bolaños-Jiménez, J., Villarroel-Marín, A.J., Parsons, E.C.M. and Rose, N. (2007) Origin and development of whalewatching in the state of Aragua, Venezuela: laying the groundwork for sustainability. Pages 16-27 in Lück, M., Gräupl, A., Auyong, J., Miller, M.L. and Orams, M.B. (Eds). Balancing Marine Tourism, Development and Sustainability. Proceedings of the V International Coastal and Marine Tourism Congress. School of Hospitality and Tourism, AUT University, the New Zealand Tourism Research Institute (NZTRI), and the School of Marine Affairs, University of Washington. Auckland, New Zealand, September 11-15, 2007.

${ }^{9}$ Pirela, D., Rojas, J., Bolaños-Jiménez, J., Márquez, R., Troncone, F., Hernández, J. and Mujica, F. (2008) Estudio Preliminar de las Interacciones entre la Actividad Pesquera, Cetáceos y Tortugas Marinas en el Golfo de Venezuela. Informe Técnico, Instituto para la Conservación y Control de la Cuenca del Lago de Maracaibo (ICLAM). Ministerio del Poder Popular para el Ambiente (MPPA), 47 pp.

${ }^{10}$ Miloslavich P. and Klein, E. (2008) Ecorregiones marinas del Caribe Venezolano. Pages 16-19 in Klein E. (Ed.). Prioridades de PDVSA en la conservación de la biodiversidad en el Caribe Venezolano. Petróleos de Venezuela, S.A. - Universidad Simón Bolívar. Caracas, Venezuela. 72 pp.
} 
Table 1. Summary of killer whale (Orcinus orca) sightings in Venezuelan waters, 1982-2008.

\begin{tabular}{|c|c|c|c|c|c|c|c|c|c|}
\hline \multirow[b]{2}{*}{ DATE } & \multirow[b]{2}{*}{ LOCATION } & \multicolumn{2}{|c|}{ COORDINATES } & \multirow[b]{2}{*}{ DEPTH } & \multirow[b]{2}{*}{$\mathrm{N}$} & \multicolumn{2}{|c|}{ SEX } & \multirow[b]{2}{*}{ REMARKS } & \multirow[b]{2}{*}{ OBSERVER/SOURCE } \\
\hline & & LAT(N) & LONG(W) & & & $\sigma$ & $\begin{array}{l}\text { Q/ } \\
\text { JUV }\end{array}$ & & \\
\hline $\begin{array}{l}\text { 1982- } \\
04-? ?\end{array}$ & $\begin{array}{l}\text { 150m off Chichiriviche de } \\
\text { la Costa }\end{array}$ & $10^{\circ} 33^{\prime} 07^{\prime \prime}$ & $67^{\circ} 14^{\prime \prime} 34^{\prime \prime}$ & 50 & 1 & & & Extremely bad weather & E. Handelman \\
\hline $\begin{array}{l}\text { 1986- } \\
\text { 03-?? }\end{array}$ & $\begin{array}{l}\text { Central Venezuela, Vargas } \\
\text { State }\end{array}$ & $10^{\circ} 43^{\prime} 00^{\prime \prime}$ & $67^{\circ} 09^{\prime} 00^{\prime \prime}$ & 400 & 3 & 1 & 2 & Photographed & E. Handelman \\
\hline $\begin{array}{l}\text { 1989- } \\
01-? ?\end{array}$ & $\begin{array}{l}\text { Approx. } 18 \mathrm{~km} \mathrm{SE} \mathrm{of} \mathrm{La} \\
\text { Tortuga from Pto. La Cruz }\end{array}$ & $10^{\circ} 46 ' 32^{\prime \prime}$ & $65^{\circ} 00^{\prime} 35^{\prime \prime}$ & 400 & 2 & & & Cariaco Trench & E. Handelman \\
\hline $\begin{array}{l}2001- \\
02-19\end{array}$ & $\begin{array}{l}\text { Sebastopol, Los Roques } \\
\text { National Park }\end{array}$ & $11^{\circ} 46^{\prime} 12^{\prime \prime}$ & $66^{\circ} 22^{\prime} 48^{\prime \prime}$ & 900 & 1 & 1 & & $\begin{array}{c}\text { Confirmed by Park } \\
\text { Ranger }\end{array}$ & T. Mata \\
\hline $\begin{array}{l}\text { Early } \\
2002\end{array}$ & $36 \mathrm{~km}$ north off La Guaira & $10^{\circ} 57^{\prime} 41^{\prime \prime}$ & $66^{\circ} 58^{\prime} 24^{\prime \prime}$ & 400 & 3 & & & Adults & E. Handelman \\
\hline $\begin{array}{l}2004- \\
01-? ?\end{array}$ & $\begin{array}{l}\text { Between Cumaná and } \\
\text { Araya Peninsula }\end{array}$ & $10^{\circ} 25^{\prime} 48^{\prime \prime}$ & $64^{\circ} 51^{\prime} 00^{\prime \prime}$ & 10 & 1 & 1 & & Videotaped by tourist & F. García \\
\hline $\begin{array}{l}2005- \\
12-28\end{array}$ & $\begin{array}{l}\text { Approx. } 8 \mathrm{~km} \text { north off } \\
\text { Tacoa }\end{array}$ & $10^{\circ} 40^{\prime} 48^{\prime \prime}$ & $67^{\circ} 04^{\prime} 48^{\prime \prime}$ & 240 & 3 & 1 & 2 & $\begin{array}{l}\text { Were tracked } 18 \mathrm{~km} \\
\text { westward }\end{array}$ & C. Mazquiarán \\
\hline $\begin{array}{l}2006- \\
01-01\end{array}$ & $\begin{array}{l}\text { Between Oricao and } \\
\text { Chichiriviche, Vargas State }\end{array}$ & $10^{\circ} 37^{\prime} 12^{\prime \prime}$ & $67^{\circ} 13^{\prime} 48^{\prime \prime}$ & 680 & 1 & 1 & & Lone adult male & C. Mazquiarán \\
\hline $\begin{array}{l}2006- \\
10-12\end{array}$ & $\begin{array}{l}\text { Approx. } 36 \mathrm{~km} \mathrm{mn} \mathrm{off} \\
\text { Tacoa }\end{array}$ & $10^{\circ} 55^{\prime} 38^{\prime \prime}$ & $67^{\circ} 07^{\prime} 32^{\prime \prime}$ & 400 & 2 & & $2 ?$ & & E. Handelman \\
\hline $\begin{array}{l}2007- \\
01-23\end{array}$ & $\begin{array}{l}\text { Between Cayo Sur and } \\
\text { Tucacas }\end{array}$ & $10^{\circ} 43^{\prime} 48^{\prime \prime}$ & $67^{\circ} 16^{\prime} 12^{\prime \prime}$ & 20 & 1 & 1 & & $\begin{array}{l}\text { Species identified by } \\
\text { marine biologist }\end{array}$ & M. Pihala \\
\hline $\begin{array}{l}2007- \\
04-14\end{array}$ & $\begin{array}{l}\text { Central Venezuela, Vargas } \\
\text { State }\end{array}$ & $10^{\circ} 43^{\prime} 48^{\prime \prime}$ & $67^{\circ} 07^{\prime} 12^{\prime \prime}$ & 288 & 5 & 3 & 2 & $\begin{array}{l}\text { Recorded by other } \\
\text { fishermen }\end{array}$ & $\begin{array}{l}\text { C. Mazquiarán } \\
\text { Oviedo et al. (2008) }\end{array}$ \\
\hline $\begin{array}{l}2007- \\
04-15\end{array}$ & $\begin{array}{l}\text { Central Venezuela, Vargas } \\
\text { State }\end{array}$ & $10^{\circ} 43^{\prime} 48^{\prime \prime}$ & $67^{\circ} 07^{\prime} 12^{\prime \prime}$ & 288 & 5 & 3 & 2 & $\begin{array}{l}\text { Recorded by other } \\
\text { fishermen }\end{array}$ & C. Mazquiarán \\
\hline $\begin{array}{l}2007- \\
04-15\end{array}$ & $\begin{array}{l}\text { Approx. } 18 \mathrm{~km} \text { north off } \\
\text { Borracha Island }\end{array}$ & $10^{\circ} 28^{\prime} 48^{\prime \prime}$ & $67^{\circ} 43^{\prime} 48^{\prime \prime}$ & 1200 & 3 & 1 & 2 & $\begin{array}{l}\text { Interacting with a } \\
\text { leatherback turtle }\end{array}$ & M. Alcará \\
\hline $\begin{array}{l}2007- \\
04-21\end{array}$ & $\begin{array}{l}\text { Central Venezuela, Vargas } \\
\text { State }\end{array}$ & $10^{\circ} 43^{\prime} 12^{\prime \prime}$ & $67^{\circ} 04^{\prime} 48^{\prime \prime}$ & 268 & 5 & 3 & 2 & $\begin{array}{l}\text { Probably same group } \\
\text { seen on } 14-15 \text { April }\end{array}$ & C. Mazquiarán \\
\hline $\begin{array}{l}2007- \\
04-22\end{array}$ & $\begin{array}{l}\text { Central Venezuela, Vargas } \\
\text { State }\end{array}$ & $10^{\circ} 45^{\prime} 00^{\prime \prime}$ & $67^{\circ} 07^{\prime} 48^{\prime \prime}$ & 240 & 5 & 3 & 2 & $\begin{array}{l}\text { Probably same group } \\
\text { seen on 14-15 April }\end{array}$ & C. Mazquiarán \\
\hline $\begin{array}{l}2007- \\
05-05\end{array}$ & $\begin{array}{l}\text { Approx. } 18 \mathrm{~km} \\
\text { northwestern of Borracha } \\
\text { Island }\end{array}$ & $10^{\circ} 24^{\prime} 36^{\prime \prime}$ & $67^{\circ} 51^{\prime} 00^{\prime \prime}$ & 600 & 3 & 1 & 2 & & D. Alemañy \\
\hline $\begin{array}{l}2007- \\
10-? ?\end{array}$ & $\begin{array}{l}\text { Approx. } 4 \mathrm{~km} \text { off } \\
\text { Caraballeda lagoon }\end{array}$ & $10^{\circ} 39^{\prime} 32^{\prime \prime}$ & $67^{\circ} 50^{\prime} 51^{\prime \prime}$ & 100 & 1 & & 1 & $\begin{array}{l}\text { Total length approx. } \\
2.5 \mathrm{~m}\end{array}$ & E. Handelman \\
\hline $\begin{array}{l}2008- \\
01-15\end{array}$ & $\begin{array}{l}\text { Approx. } 80 \mathrm{~km} \text { north off La } \\
\text { Guaira to Los Roques }\end{array}$ & $10^{\circ} 18^{\prime} 00^{\prime \prime}$ & $67^{\circ} 48^{\prime} 00^{\prime \prime}$ & 1500 & 4 & 1 & 3 & & C. Mazquiarán \\
\hline
\end{tabular}

The remaining 22\% corresponded to the 'Central Coast' $(11 \%)$, 'Oceanic Islands' (5.5\%) and the 'Cariaco Trench' $(5.5 \%)$ ecoregions. The Oceanic eco-region is defined as 'The territorial and Exclusive Economic Zone (EEZ) waters, deeper than 200m; ecosystems are pelagic and deep' (Miloslavich and Klein, 20087). The Eastern Upwelling ecoregion is characterized by 'a shallow continental shelf with coarse sandy bottoms and rocky shores; high primary and secondary production due to seasonal upwelling fronts, including the islands of Margarita, Coche, Cubagua, Los Frailes, Los Hermanos and Los Testigos' (Miloslavich and Klein, 2008).

Four sightings were recorded in the Oceanic ecoregion off Vargas State during two consecutive days of two consecutive weekends in late April 2007. Observers remarked that they may have corresponded to the same group, but this could not be confirmed due to a lack of photographic documentation. This group consisted of five individuals, determined to be three adult males and two females or juveniles of undetermined sex, on the basis of size and shape of the dorsal fin and body length ${ }^{11}$

\footnotetext{
${ }^{11}$ C. Mazquiarán, pers. comm., 2007, Universidad Católica Andrés Bello, UCAB, see Table 1.
} 


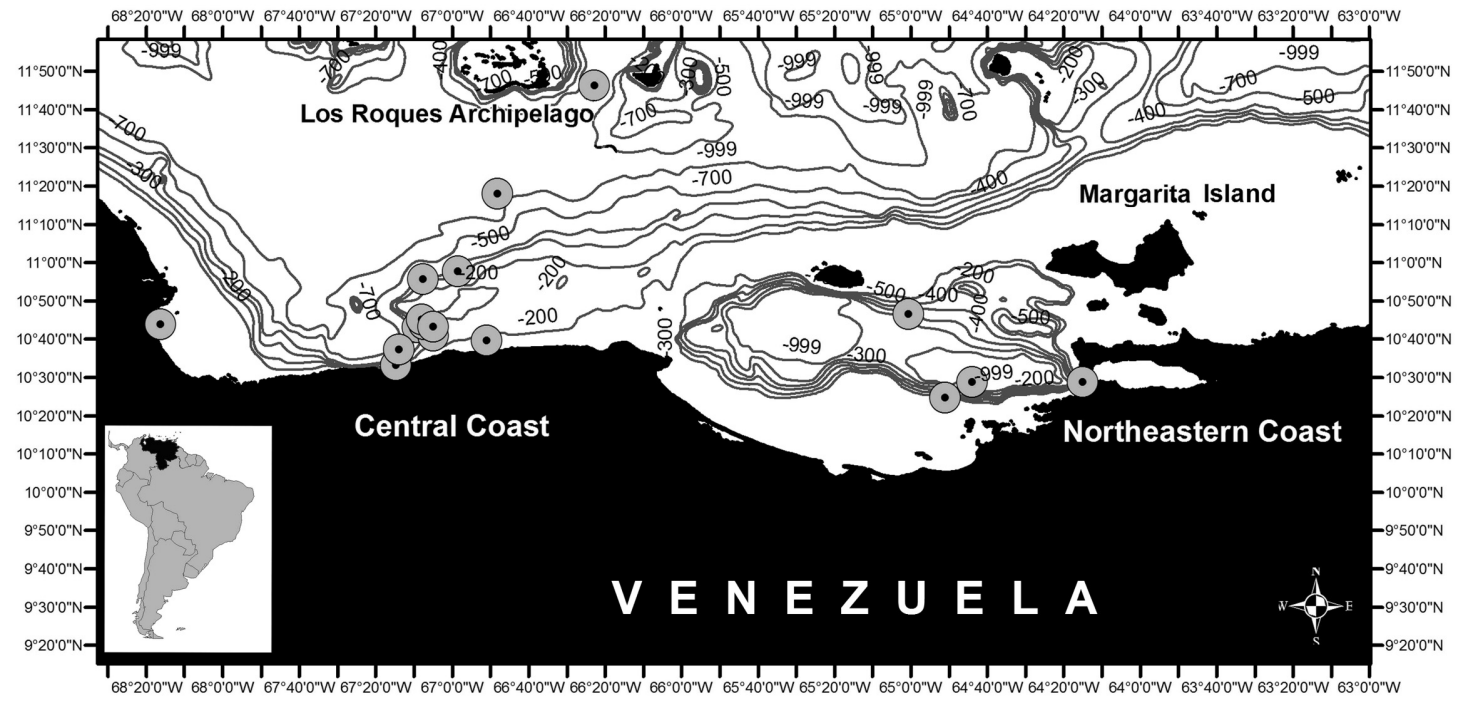

Figure 1. Distribution map of killer whale (Orcinus orca) sightings in Venezuelan waters, 1982-2008 (map produced by L. Oviedo).
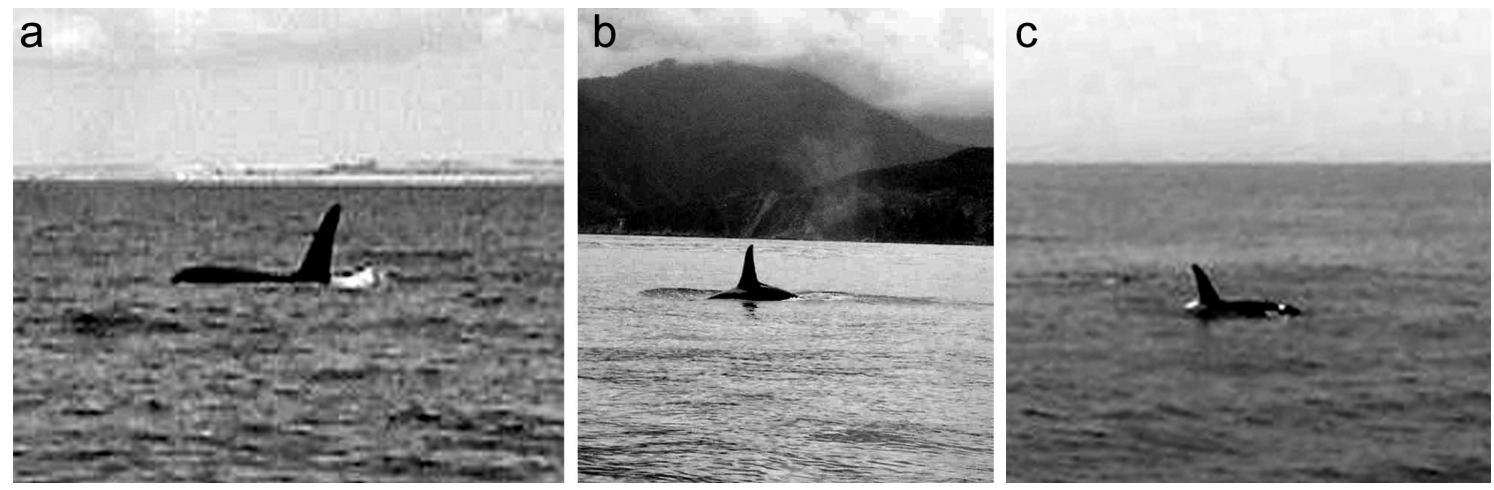

Figure 2. (a) A male killer whale sighted off Araya Peninsula, State of Sucre, January 2004 (anonymous video/photograph courtesy E. González and F. García). (b) A male killer whale sighted off the State of Vargas, Central Venezuela, 1 January 2006 (photograph by C. Mazquiarán). (c) A male killer whale sighted over the Cariaco Trench, 5 May 2007 (photograph by D. Alemañy).

A noteworthy incident was a videotaped attack by two killer whales on a leatherback turtle (Dermochelys coriacea) off northeastern Venezuela on 15 April 2007 (footage available online at: http:/ / www.youtube.com/ watch?v=qezONiWcFjU; see also Oviedo et al., 2008). The encounter ended when the adult female of the pair took the turtle in its mouth and dove to a depth of greater than $100 \mathrm{~m}$ (determined by echosounder; Raymarine E120), but observers were not able to determine if the turtle was eaten. The videotaped individuals were an adult female and a subadult of undetermined sex (Oviedo et al., 2008). During the whole interaction, an adult male was observed surfacing at a distance of about $500 \mathrm{~m}$ from the boat and the two whales involved in the attack (Oviedo et al., 2008).
Eighty-three percent of the records were from December through May. Some observers remarked on the apparent co-occurrence of killer whales with cold water incursions that would coincide with the presence of known prey species, such as tunas and billfish $^{12,13}$, but this requires further investigation. Consumption of tunas and billfish by killer whales has been documented elsewhere in the Atlantic Ocean, including predation on longline fishery captures (e.g. Secchi and Vaske, 1998; Dalla Rosa and Secchi, 2007; Hernández-Milian et al., 2008). Links between tuna and billfish peak occurrence and killer whale sightings have been suggested for other areas of the Atlantic Ocean including the western North Atlantic and the Straits of Florida (Katona et al., 1988), the Bahamas

${ }^{12}$ C. Mazquiarán, pers. comm., 2007, Universidad Católica Andrés Bello, UCAB, see Table 1.

${ }^{13}$ E. Haldeman, pers. comm., 2009, Caraballeda Yachting Club, see Table 1. 
(Dunn et al., 2007 ${ }^{14}$ ), the Strait of Gibraltar (Guinet et al., 2007; de Stephanis et al., 2008), Brazil (Secchi and Vaske, 1998; Dalla Rosa and Secchi, 2007) and Uruguay (Passadore et al., 2008). Also, as noted by Katona et al. (1988) and Passadore et al. (2007), since oceanic variables affect tuna prey distribution, the timing of tuna migration is somewhat variable, which in turn may affect occurrence of the killer whale in this area.

There is currently not enough information to speculate on any seasonality to the occurrence of the killer whale in Venezuelan waters. In Brazil, it has been hypothesized that killer whales could use shallow, coastal habitats in the State of Rio de Janeiro as feeding grounds on a seasonal basis (Siciliano et al., 1999). This is consistent with the results of the study of interactions of killer whales with the longline fishing fleet off Brazil, which reported that interactions occurred primarily from June to February (Secchi and Vaske, 1998). It is also unknown whether some of the sightings reported here represent the same individuals; only solid photo-documentation and biopsy efforts would be able to address such questions. Further collaborative efforts are needed to evaluate the presence of the killer whale (and other cetacean species) in coastal and offshore areas of the Venezuelan Exclusive Economic Zone, as well as elsewhere in the western Atlantic.

\section{Acknowledgements}

We thank David Alemañy, Francisco García, Ernani Handelman, Toribio Mata, Carlos Mazquiarán, and Mikko Pihala, who provided photographs and/or information on the sightings. Miguel Alcará and Arturo Barrios also provided a copy of the original footage and information of the sea turtle interaction. Eduardo González and Bladimir Rodríguez helped us to locate original observers for several records. Freddy Arocha, Eduardo Klein, Renaud de Stephanis, Giuseppe Notarbartolo di Sciara and Salvatore Siciliano provided useful information and/or literature. William Evans was kind enough to answer questions on his work in the region in the 1970s. Lenín Oviedo produced the map in Figure 1 and assisted in other aspects of the paper. We also thank the Commander and personnel from the Puerto Cabello Hydrographic Station of the Armada de la República Bolivariana de Venezuela (OCHINA Office of The Venezuelan Navy, ARBV), and especially MT1(ARBV) José Antonio Martínez and MT1(ARBV) Ferrer Alvarez, who helped to determine the bottom depth for 12 of the sighting locations. Tahís Lugo helped determine the bottom depth of sightings by Ernani Handelman. The manuscript was greatly improved by comments from Thomas Jefferson, Carlos Lasso, Chris Parsons and Ingrid
Visser and editorial advice from Nelio Barros, David Aurioles and Daniel Palacios. Attendance by the senior author to the 2008 IWC meeting in Santiago, Chile, was funded by Cetacean Society International and the International Fund for Animal Welfare.

\section{References}

Acevedo-Galindo, R. (2007) Potential geographical distribution of seven species of marine cetaceans reported in Venezuela, Southeast Caribbean. Acta Zoologica Sinica 53(5): 853-864.

Caldwell, D.K. And Caldwell, M.C. (1969) Addition of the leatherback sea turtle to the known prey of the killer whale, Orcinus orca. Journal of Mammalogy 50: 636.

Dalla Rosa, L. And SECCHI, E.R. (2007) Killer whale (Orcinus orca) interactions with the tuna and swordfish longline fishery off southern and south-eastern Brazil: a comparison with shark interactions. Journal of the Marine Biological Association of the United Kingdom 87: 135-140.

De Stephanis, R., Cornulier, T., Verborgh, P., Salazarsierra, J., Pérez Gimeno, N. And Guinet, C. (2008) Summer spatial distribution of cetaceans in the Strait of Gibraltar in relation to the oceanographic context. Marine Ecology Progress Series 353: 275-288.

Evans, W.E., Jehl, J.R., And Wolson, F.H. (1979) Current studies on distribution and abundance of cetaceans in Venezuela. Working paper 13 presented to the IWC Subcommittee on small cetaceans, 22-29 June 1979, Cambridge, England. [Available from the Office of the International Whaling Commission, The Red House, 135 Station Road, Impington, Cambridge, Cambridgeshire CB4 9NP, UK].

Guinet, C., Domeneci, P., Barret-Lennard, L., Ford, J K.B. And Verborgh, P. (2007) Killer whale predation on bluefin tuna: exploring the hypothesis of endurance-exhaustion technique. Marine Ecology Progress Series 347:111-119.

Hernández-Milián, G., Goetz, S., Varela-Dolpico, C., RodríguezGutiérrez, J., Romón-Olea, J., Fuertes-Gamundi, J.R., UlloA-Alonso, E., Tregenza, N.J.C., Smerdon, A., Otero, M.G., Tato, V., Wang, J., Begoña-Santos, M., López, A., Lago, R., Portela, J.M. and Pierce, J. (2008) Results of a short study of cetaceans and longline fisheries in Atlantic waters: environmental correlates of catches and depredation events. Hydrobiologia 612: 251-268.

Herrera-Trujillo, O.L. (2007) Efecto de la presencia de peñeros a motor sobre el comportamiento del delfín manchado del Atlántico (Stenella frontalis) y del delfín nariz de botella (Tursiops truncatus) en la costa del Estado Aragua. B.Sc. Thesis, Universidad Central de Venezuela. 86 pp.

IWC (International Whaling Commission) (2006) Chair's Report of the $57^{\text {th }}$ Annual Meeting, Ulsan, Republic of Korea. 77 pp. [Available from the Office of the International Whaling Commission, The Red House, 135 Station Road, Impington, Cambridge, Cambridgeshire CB4 9NP, UK].

IWC (International Whaling Commission) (2007) Chair's Report of the $58^{\text {th }}$ Annual Meeting, St. Kitts and Nevis, 77pp. [Available from the Office of the International Whaling Commission, The Red House, 135 Station Road, Impington, Cambridge, Cambridgeshire CB4 9NP, UK].

\footnotetext{
${ }^{14}$ Dunn, C.A., Claridge, D.E. and Pusser, T.L. (2007) Killer whale (Orcinus orca) occurrence and predation in the Bahamas. In Abstracts, $17^{\text {th }}$ Biennial Conference on the Biology of Marine Mammals, 29 November - 3 December 2007, Cape Town, South Africa.
} 
IWC (International Whaling Commission) (2008) Chair's Report of the $59^{\text {th }}$ Annual Meeting, Anchorage, Alaska, USA. 62 pp. [Available from the Office of the International Whaling Commission, The Red House, 135 Station Road, Impington, Cambridge, Cambridgeshire CB4 9NP, UK].

Katona, S.K., BeARD, J.A., GirTon, P.E. And WenZel, F. (1988) Killer whales (Orcinus orca) from the Bay of Fundy to the equator, including the Gulf of Mexico. Rit Fiskideildar 11: 205-224.

Miloslavich, P., Klein, E., Yerena, E. and Martin, A. (2003) Marine biodiversity in Venezuela: status and perspectives. Gayana 67(2): 275-301.

Molero-Lizarraga, A. (2005) Distribución y abundancia relativa de cetáceos en la ruta marítima Isla de Margarita-Cumaná. B.Sc. Thesis, La Universidad del Zulia. 60 pp.

NAVEIRA-CORTIZAS, J.L. (1996) El orden Cetacea en la región nororiental de Venezuela. M.Sc. Thesis, Universidad de Oriente, 181 pp.

Oviedo, L. AND SiLva, N. (2005) Sighting frequency and relative abundance of bottlenose dolphins (Tursiops truncatus) along the northeast coast of Margarita Island and Los Frailes Archipiélago, Venezuela. Revista de Biología Tropical 53(3-4): 595-600.

Oviedo, L., Silva, N., Bermúdez, L. and Odell, D.K. (2005) Distribution of bottlenose dolphins (Tursiops truncatus) on the east coast of Isla Margarita and the Los Frailes Archipelago, Venezuela. Aquatic Mammals 31(4): 442-446.

Oviedo, L., Esteves, M.A., Alfe, E. Acevedo-Galindo, R. And
Bolaños-JimÉneZ, J. (2008) Interaction between killer whales (Orcinus orca) and a leatherback turtle (Dermochelys coriacea) off northeastern Venezuela. JMBA2 - Biodiversity Records. Available electronically at http://www.mba.ac.uk/jmba/ pdf/6156.pdf.

Passadore, C., Szephegyi, M. and Domingo, A. (2008) Presencia de mamíferos marinos y captura incidental en la flota uruguaya de palangre pelágico (1998-2007). Collective Volume of Scientific Papers, ICCAT 62(6): 1851-1857. Available electronically at http:// www.iccat.int/ Documents / CVSP / CV062_2008/no_6/ CV062061851.pdf.

Passadore, C., M. Szephegyi, Mora, O. and Domingo, A. (2007) La flota de palangre como fuente de información sobre la distribución de la orca (Orcinus orca) en el océano Atlántico sudoccidental (20022006). Collective Volume of Scientific Papers, ICCAT 60(6): 2118-2129. Available electronically at http://www.iccat.int/Documents/ CVSP/CV060_2007/no_6\%5CCV060062118.pdf.

SeCCHI, E.R. AND VASKE, T., JR. (1998) Killer whale (Orcinus orca) sightings and depredation on tuna and swordfish longline catches in southern Brazil. Aquatic Mammals 24: 117-122.

Siciliano, S., Lailson-Brito, J., Jr. and De Azevedo, A. (1999) Seasonal occurrence of killer whales (Orcinus orca) in waters of Rio de Janeiro, Brazil. Zeitschrift für Sängetierkunde 64: 251-255.

Silva-Hernández, M.G. (2007) Abundancia y distribución de los cetáceos presentes en el Estado Aragua. B.Sc. Thesis, Universidad Central de Venezuela. 100 pp. 